\title{
Kütüphanelerde Performans Ölçümü: IFLA Performans Ölçütlerinin Değerlendirilmesi
}

\section{Performance Measurement in Libraries: Evaluation of IFLA Performance Measurement Criteria}

\author{
Asiye KAKIRMAN YILDIZ*
}

\begin{abstract}
Öz
Bu çalışmada, IFLA tarafından 1996 yılında ilk baskısı yapılan "Akademik Kütüphanelerde Performans Ölçümü" adlı kitabın, 2007yılında gözden geçirilerekikincibaskısının "Kütüphanelerde Performans Ölçümü" adı altında yapılmasının nedenleri ve bu iki baskının karşılaştırmalı bir değerlendirmesi yapılmıştır. Aradan geçen 11 yıllık süre içerisinde meydana gelen değişimlerin, kütüphanelerin performansını değerlendirmek için kullanılan ölçütlerde nasıl değişiklik yarattığı görülecek ve bu kitaplar çerçevesinde, yaşanan değişimlerin kütüphanelere olan etkisi tartışılacaktır.
\end{abstract}

Anahtar sözcükler: Değişim, Kütüphane, Performans ölçümü, Performans değerlendirme, IFLA

\section{Abstract}

This study consists of a comparative analysis of the reasons that led to the production of two different editions of the book "Performance Measurement in Libraries" (2007), which had previously been published as "Performance Measurement in Academic Libraries" in 1996. This study will discuss the innovations and changes that took place during the eleven years between two editions and their impacts on the performance evaluation of libraries.

Keywords: Change, Library, Performance measurement, Performance appraisal, IFLA

\section{Giriş}

Yaşayan bir sistem ve kâr amacı gütmeyen bir hizmet işletmesi olarak kütüphanelerin, dünyada yaşanan gelişme ve değişimlere kayıtsız kalması mümkün değildir. Amacı, hedefi ve kitlesi olan her kurum gibi kütüphaneler de değişime uygun olarak, hitap ettiği kitlenin ihtiyaçlarına cevap vermek, beklentilerini karşılamak ve bu beklentiler

* Dr., Marmara Üniversitesi Fen Edebiyat Fakültesi Bilgi ve Belge Yönetimi Bölümü, (akakirman@marmara.edu.tr) 
doğrultusunda hizmet kalitesini yüksek tutmak durumundadır. Söz konusu gelişme ve değişimler, sunulan hizmetin kaliteli olmasını sağlamak amacıyla kütüphanelerin gerek kullanıcı hizmetleri gerekse derme geliştirme politikaları açısından yeniden değerlendirilmelerini zorunlu kılmaktadır. Bu değerlendirmenin doğru ve sağlıklı bir şekilde yapılabilmesi ise, kütüphane performans ölçütlerinin oluşturulmasına ve hizmetlerin bu ölçütler ışığında ölçülmesine bağlıdır.

En basit tanımıyla verimliliğin ölçülmesi anlamına gelen performans, yapılan değerlendirmeler sonucunda kütüphanenin, hangi alanlarda eksik olduğunu ortaya koymakta ve değişimin o alandaki eksikliğin giderilmesiyle başlamasını sağlamaktadır. Kütüphanelerde performans değerlendirmesi konusu, kullanıcı odaklı hizmetler verebilmek amacıyla, son yıllarda kütüphanelerin ve kütüphanecilerin gündemini oldukça meşgul etmektedir. Bu konuda yapılan çalışmalar sonucunda, kütüphaneler için performans ölçütleri belirlenmiş ve ISO 11620 (Kanık, 1999, s.146), ISO TR 20983, EQLIPSE ve EQUINOX gibi (Poll ve Boekhorst, 2007, s.262) gibi uluslararası standartlar hazırlanmış ve çalışmalar yapılmıştır. Teknolojik gelişmeler ile iç ve dış çevrede meydana gelen değişiklikler, kullanıcı ihtiyaç ve beklentilerini şekillendirmekte ve kullanıcıların bilgi edinme yaklaşımında farklılıklar görülmesine neden olmaktadır. Dolayısıyla kütüphanelerin değişime ve gelişmelere uyum sağlayabilmeleri için, performans ölçütlerini güncellemeleri zorunluluk olarak görülmektedir.

Bu çalışmanın amacı, IFLA tarafından 1996 ve 2007 yıllarında iki ayrı baskısı yapılarak yayınlanan "Kütüphanelerde Performans Ölçümü" adlı kitabın iki basımı arasında, hazırlandıkları dönemin özellikleri de dikkate alınarak değişimin kütüphanelere olan etkisini ve bu etkinin kütüphane hizmetlerine yansımasını incelemektir. Akademik kütüphaneler için hazırlanan kitabın ilk baskısı, 7 genel başlık altında 17 performans ölçütünden oluşmaktadır (Poll ve Boekhorst, 1996, s.41). 2007 yılında ise belirlenen ölçütlerin değişen ihtiyaçlar karşısında artık yetersiz kaldığı görülmüş ve kitap gözden geçirilerek aynı yıl yeniden yayımlanmıştır. Bu baskıda kütüphane performans ölçütleri 4 ana başlık altında 40 ölçütten oluşmuş ve bütün kütüphane türlerine uygulanabilir hale getirilmiştir. (Poll ve Boekhorst, 2007, ss.43-45).

Bu çalışmada, gelişen ve değişen ihtiyaçlar sonucunda farklı yıllarda farklı baskıları yapılan 2 aynı / ayrı kitap ele alınmıştır. Bu kitaplar ön analiz, kategorilendirme ve çıkarsama gibi aşamaların takibi neticesinde değerlendirilmiştir. Dolayısıyla, çalışma sırasında kullanılan araştırma yöntemini, çok çeşitli söylemlere uygulanan bir takım metodolojik araç ve tekniklerin bütünü olarak tanımlanan “içerik analizi teknikleri"olarak belirlemek doğru olacaktır. Nitekim içerik analizi teknikleri, kontrollü bir yorum çabası olarak ve genellikle tümdengelime dayalı bir okuma aracı olarak da nitelendirilmektedir (Bilgin, 2006, s.1). 


\section{Kütüphanelerde Performans Değerlendirme}

Literatürde performans değerlendirme ile ilgili pek çok tanım yapılmıştır. Genel olarak belirtmek gerekirse performans değerlendirme, kurumun misyon, hedef, amaç ve vizyonuna erişebilmesi için, gerekli performans standart ve göstergelerinden faydalanarak, kurumun maddi ve manevi bütün varlıklarının ölçülmesi ve değerlendirilmesi sürecidir (Çakmak ve Ocaklı, 2006, s.214). Bu ölçme ve değerlendirme sürecinde kullanılan performans standart ve göstergelerinin kütüphanelerin faaliyet amaçlarına ve hizmet sunuş şekillerine bağlı olarak farklılık göstermesi ise son derece doğaldır (Karakaş, 1991, s.170).

Kütüphanelerde performans değerlendirilmesine yönelik yapılan çalışmalara örnek oluşturan ve kütüphane araştırmalarında kullanıcılarla kurulan ilk önemli ilişki 1940'ın sonlarına rastlamaktadır. Daha önce yapılan kullanıcı odaklı çalışmaların çoğu bilgi davranışı ve kullanıcı gereksinimlerine yönelik olmuştur. 1970'lerde ise kullanıcıların, kütüphanelerin değerlendirilmesinde önemli bir konumda olduğu görüşü önem kazanmış ve 1970'lerin ortalarına kadar yöntem üzerine yoğunlaşılmıştır (Akbayrak, 2005, s.31).

Kütüphanelerde performans değerlendirme konusu, son dönemlerde kütüphanelerde yaşanan gelişmeler ve değişimlerle birlikte tekrar ele alınmış ve bu değişimler sonucunda yaşanan hizmet sunumları ve çeşitlilikleri, birer performans göstergesi olarak kabul edilmiştir. Diğer bir deyişle, aynı amaca hizmet eden kütüphanelerden fark yaratan ya da daha farklı hizmet sunanlar, kullanıcı açısından başarılı kabul edilmiştir. Özellikle elektronik kaynakların ve hizmetlerin de kütüphanelerde yer almaya başlamasıyla birlikte ortaya çıkan hizmet ve kaynak çeşitliliği, kütüphanelerin verimliliğini değerlendirebilecek olan performans ölçütlerinin bir standarda bağlanmasını gerekli kılmıştır.

Bu konudaki ilk standart çalışması 1998 yılında ISO tarafından yapılmıştır. ISO 11620 adını taşıyan standart, 2008 yılında gözden geçirilerek yeniden yayımlanmıştır. Dört temel başlık altında 45 ölçütten oluşan ISO 11620'nin altını çizdiği konu başlıklarını şu şekilde özetlemek mümkündür (ISO 11620, 2008, ss.15-18):

1- Kaynaklar, Erişim ve Altyapı: Bu ölçüt grubu, kütüphane kaynaklarının ve hizmetlerinin, yetkinliğinin ve verimliliğinin ölçülmesini amaçlamaktadır.

2- Kullanım: Bualandaki ölçütlerin amacı, kütüphane kaynaklarının ve hizmetlerinin kullanım oranını ölçmektir.

3- Etkinlik (Verimlilik): Bu ölçüt grubu kütüphane kaynak ve hizmetlerinin verimliliğini ölçmeyi amaçlamaktadır.

4- Mevcut yetkinlikler ve gelişme: Bu alandaki performans ölçütleri, kütüphanenin mevcut hizmet ve kaynaklarının değerlendirilmesini ve bu değerlendirmeye paralel olarak muhtemel gelişim seyrini göstermektedir. 
Ülkemizde daha yavaş olmakla birlikte yurt dışı örneklerinde standartları uygulayan ya da kendi hedeflerini belirleyip bu hedefler doğrultusunda ilerlemeyi amaçlayan kütüphane çalışmaları görülmektedir. Bu çalışmalarda performans ölçütleri genellikle yukarıda sıralanan konu başlıklarından oluşmaktadır. Ancak, daha önce de belirtildiği gibi kütüphanelerin intiyaç ve amaçlarına bağlı olarak farklılıklar da göstermektedir (Law, Gao ve Ng, 2009, ss.79-81).

Bütün kütüphane türlerine yönelik olarak hazırlanan standart çalışmasının en önemli noktasını ise kıyaslama (benchmarking) oluşturmaktadır. "Kurumsal karne (Balanced Scorecard)" yaklaşımıyla hazırlanan ölçütlerin uygulama sonuçlarının değerlendirilebilmesi için, kütüphane ile benzer faaliyet amaçları taşıyan bir başka kütüphanenin kıyaslanması önerilmektedir. Pek çok nedenden dolayı bir ölçütün değerlendirme sonucunun "iyi" ya da "kötü" olarak değerlendirilmesinin oldukça zor olduğu belirtilirken, bir sonucun iyi ya da kötü olmasının o kütüphanenin özellikleri ile de ilgili olduğu vurgulanmaktadır (ISO 11620, 2008, s.14). Özellikle yurt dışı uygulamalarında istatistiklerden elde edilen verilerin, kütüphanelerin performans değerlendirmesinde ve bu sonuçların benzer amaçlar taşıyan diğer kütüphanelerle kıyaslama konusunda kullanılması, kurumsal karne yaklaşımını destekler niteliktedir (Liu, 2001, s. 189-191).

Literatüre bakıldığında performans değerlendirmesi konusunda ya bilgi merkezlerinin gereken ilgiyi göstermediğinden (Çakmak ve Ocaklı, 2006, s.212) ya da kütüphanelerin etkinliğini değerlendiren ölçütlerin teoride kalmasından ve bu ölçütlerin uygulama sonuçlarını içeren raporların olmamasından şikâyet edildiği görülmektedir (Poll, 2008, s.30). Şikâyet edilen durum günümüzde de devam etmekle birlikte, pek çok kütüphanenin (yayınlanmasa bile) amaçlarına bağlı olarak kendi performans ölçütlerini hazırlayarak web sitelerinde yayımladıkları ve belli dönemlerde hizmet ve kaynaklarını değerlendirdikleri görülmektedir. Bu gelişmeyi de göz önünde tutarak, kütüphanelerde performans değerlendirme konusunun, dünyada son derece yaygın ve önemli bir kullanım alanına sahip olmaya başladığını söylemek yanlış olmayacaktır.

\section{IFLA Performans Ölçütleri: Karşılaştırmalı Bir İnceleme}

Başlangıçta sadece akademik kütüphaneler için hazırlanan performans ölçütleri ilk kez 1996 yılında yayımlanmıştır. IFLA tarafından yürütülen çalışma, çeşitli ülkelerden katılan çalışma gruplarından oluşan bir komite tarafından 5 yılda hazırlanmıştır. Çalışmada özellikle vurgulanan husus, akademik kütüphanelerin her ne kadar "akademik kütüphane" başlığı altında toplansalar da, gerek yapıları, gerekse faaliyetleri bakımından birbirinden farklı özellikler taşıdığıdır. Dolayısıyla belirlenen ölçütlerin değişen ihtiyaçlar karşısında sayısının artıılacağı ya da azaltılacağı ve intiyaca cevap verir hale getirileceği belirtilmiştir (Poll ve Boekhorst, 1996, s.8.). 
Kitapta yer alan ve önemine dikkat çekilen bir başka konu, akademik kütüphanelerdeki performans ölçüm faaliyetlerinin belirli aralıklarla tekrar edilmesinin gerekli olduğudur (Poll ve Boekhorst, 1996, s.8.). Nitekim önemli olan bu ölçütleri bir kez uygulayıp bırakmak değil, ilk ölçümden itibaren yaşanan değişimi görebilmektir.

Kütüphanelerin performans göstergeleri hesaplanırken, girdi ve çıktı miktarları değerlendirilirken ya da hizmetlerinin nitelikleri ölçülürken dikkate alınan temel ölçüt kullanıcı memnuniyetidir (Stephens ve Russell, 2004, ss.248-249). Kullanıcı memnuniyetinin ana bileşenlerinden ikisi ise; kullanıcının istediği bilgiye uzaktan erişim rahatlığına sahip olması ve yüksek hizmet beklentisidir. Bu iki faktörün doğal sonucu olarak kütüphaneler, bilgi hizmetlerindeki ve kaynaklarındaki çeşitliliği kullanıcı ihtiyaç ve beklentilerine göre yeniden şekillendirmek zorunda kalmışlardır. Dolayısıyla bu ölçüt, kütüphanelerin performanslarının değerlendirilmesinde ve kütüphane programlarının planlanmasında doğrudan etkili olmaktadır.

Kullanıcı memnuniyeti, kütüphanelerin performans derecesini ve hizmet kalitesini ölçmek için IFLA tarafından hazırlanan ilk kitapta performans ölçütlerinden biri olurken, kütüphanenin dermesi ve stratejik önemi de diğer ölçütler arasında yer almaktadır. Kitabın her iki baskısında da ortak olan bu konular şu şekilde ifade edilmiştir:

1- Kullanıcı Memnuniyeti: Kütüphane tarafından sunulan hizmet ve kaynakların kullanıcıyı ne kadar tatmin ettiğidir. Kullanıcı memnuniyeti ölçütleri arasında kullanıcıların kütüphane personelinden, kütüphanenin açılış kapanış saatlerinden memnuniyeti ve istediği kaynağa erişim sayılabilir. Kullanıcı memnuniyetini test etmek için geliştirilen ve özellikle üniversite kütüphanelerindeki hizmet kalitesini ölçmeyi hedefleyen araçlar olan LibQual ve ServQual ile kullanıcılara anket uygulanarak alınan cevaplar doğrultusunda kütüphane hakkında bir değerlendirmeye sahip olunabilmektedir (Poll ve Boekhorst, 1996, s.106).

2- Derme ve Kullanımı: Dermenin büyüklüğü, kütüphane kaynaklarının kullanımı ve kütüphane hizmetlerinin niteliğinin ölçülmesidir. Kütüphane hizmetlerinin nitelikleri, kütüphane çalışanları (çalışan sayısı, eğitim seviyeleri vb.), bütçesi (personel bütçesi, derme bütçesi, teknolojik yatırımı vb.), kütüphane hizmetlerinin kullanılabilirliği (ödünç alma, yayın rezervi vb.) ve elektronik hizmetlerin kullanılabilirliğini (elektronik veri tabanları, e- dergiler, e-kitaplar vb.) kapsamaktadır. Bu ölçümlerin yapılabilmesi için kütüphanelerde tutulan günlük istatistikler ve bunların değerlendirilmesiyle elde edilen veriler yeterli olacaktır (Poll ve Boekhorst, 1996, s.56).

3- Stratejik Önem: Kütüphanenin stratejik önemi, kütüphanenin yer aldığı ya da bağlı bulunduğu kurum ve kullanıcıları açısından taşıdığı önemi göstermektedir. Bu itibarla sorulacak en önemli soru "kütüphane olmasaydı" şartlı sorusudur. Bu soruya verilecek cevap, kütüphanenin kullanıcıları için bilgi ihtiyacını karşılayıp 
karşılayamadığı ile ilgili olacaktır. Kütüphanenin stratejik önemi, kısa sürede değerlendirilebilecek bir ölçüt değildir. Dolayısıyla belli bir süreç içerisindeki intibalar toplanarak bir sonuca ulaşmak mümkün olacaktır. (Poll ve Boekhorst, 1996, ss.20-22)

Tablo 1. IFLA Kütüphane Performans Ölçütleri 1996 (Poll ve Boekhorst, 1996, s.41)

\begin{tabular}{lll}
\hline Genel Kütüphane Kullanımı & Katalog Kalitesi & Uzaktan Erişim \\
\hline 1-Kütüphanenin etkisi & 3-Bilinen başlığı arama & $\begin{array}{l}\text { 5- Kişibaşına düşen uzaktan } \\
\text { kullanım oranı }\end{array}$ \\
\hline 2-Açık olduğu saatler & 4- Konu taraması & \\
\hline
\end{tabular}

\begin{tabular}{|c|c|c|}
\hline Derme Kalitesi & Dermeye Erişim & Referans Hizmeti \\
\hline 6-Kontrol listesi & 10- Sağlama hızı & $\begin{array}{l}\text { 15- Doğru cevap verme } \\
\text { oranı }\end{array}$ \\
\hline 7-Derme kullanımı & 11- Kitap süreç hızı & \\
\hline 8-Konusal derme kullanımı & 12- Erişilebilirlik & Kullanıcı Memnuniyeti \\
\hline \multirow[t]{2}{*}{ 9-Dokümansız kullanım } & 13- Doküman gerigetirim süresi & 16-Kullanıcı memnuniyeti \\
\hline & 14- Kütüphanelerarası işbirliği hızı & $\begin{array}{l}\text { 17- Uzaktan erişim için } \\
\text { kullanıcıya sunulan } \\
\text { hizmetin memnuniyet } \\
\text { derecesi }\end{array}$ \\
\hline
\end{tabular}

Kitabın ilk baskısında yer alan performans ölçütleri yedi genel kategori altında 17 başııktan oluşmaktadır (Bkz. Tablo 1). Ölçütlerin tespit edilmesi sürecinde komite tarafından özellikle dikkat edilen hususlar ve bu hususlara bağlı olarak belirlenen ölçütler şunlar olmuştur (Poll ve Boekhorst, 1996, s.11):

$\diamond$ Akademik kütüphaneler üzerine odaklanmak.

$\diamond$ Bütün ülkelerde uygulanabilecek özelliklere ve ayrıntılara sahip ölçütler belirlemek.

$\diamond$ Ölçütlerin büyük/küçük veya otomasyona geçmiş ya da geçmemiş fark etmeksizin, bütün akademik kütüphanelere uygulanabilir olmasına dikkat etmek.

$\diamond$ Kullanıcı odaklı bir yaklaşım benimsemek

$\diamond$ Kullanıcı memnuniyeti gibi bütün kütüphaneler için önemli olan son derece kapsamlı ölçütler belirlemek.

2007 yılında ihtiyaçlara bağlı olarak güncellenen kütüphane performans ölçütleri, dört kategori altında 40 ana başlıktan oluşmaktadır. İlk baskıdan farklı olarak, ikinci ve genişletilmiş olan baskıda elektronik kaynaklara ve hizmetlere de yer verilmiştir. İlk 
baskıda yalnızca iki alanda elektronik hizmetlerden bahsedilirken, ikinci baskıda yedi alan elektronik kaynaklara ve hizmetlere ayrılmış; diğer alanların büyük çoğunluğu ise geleneksel ve elektronik hizmetlerin birleşmesinden meydana gelmiştir (Bkz. Tablo 2).

Tablo 2. IFLA Kütüphane Performans Ölçütleri 2007 (Poll ve Boekhorst, 2007, ss.5-6)

\section{A-Kaynaklar, Alt yapı sistemi}

A.1. Kişi başına düşen kullanıcı alanı

A.2. Kişi başına düşen oturma yeri sayısı

A.3. Kullanıcı istekleri ile karşılaştıııldığında açık olduğu saatler

A.4. Kişi başına düşen bilgi sağlama masrafı

A.5. Aranan yayınların mevcudiyeti

A.6. Cevaplanamayan soru oranı

A.7. Kütüphaneler arası işbirliğinde alınan isteklerin gerçekleştirilme oranı

A.8. Anında erişim

A.9. Kişi başına düşen personel sayısı

A.10. Ana sayfadan doğrudan erişim

\section{B- Kullanım}

B.1. Pazara nüfuz etme/ pazara giriş

B.2. Kullanıcı memnuniyeti

B.3. Kütüphanenin fiziksel kullanım oranı (Kişi başına düşen)

B.4. Oturma yerlerinin doluluk oranı

B.5. Elektronik belge indirme sayısı (Kişi başına düşen)

B.6. Derme kullanımı

B.7. Kullanılmayan dermeun yüzdelik oranı

B.8. Kütüphane içi ödünç verme oranı (Kişi başına düşen)

B.9. Kütüphane dışı ödünç verme oranı (Kişi başına düşen)

B.10. Kullanıcı eğitimlerine katııım oranı (Kişi başına düşen)

B.11. Danışma sorularının miktarı (Kişi başına düşen)

B.12. Faaliyetlere katılım oranı ( Kişi başına düşen) 


\section{Potansiyel Güç ve Gelişme Durumu}

D.1. Elektronik dermelara yapılan sağlama harcamalarının yüzdelik oranı

D.2. Elektronik hizmetleri sağlayan ve geliştiren kütüphane personelinin yüzdelik oranı

D.3. Kişi başına düşen eğitim dersi sayısı

D.4. Özel yardımlar ya da bağışlar yoluyla desteklenme oranı

D.5. Kütüphaneye ayrılan kurumsal desteklerin oranı

\section{C- Verimlilik}

C.1. Her bir kullanıcının maliyeti

C.2. Kütüphanenin hem fiziksel hem de elektronik olarak kullanılmasının kütüphaneye maliyeti

C.3. Her bir kullanımın maliyeti

C.4. Dermeun maliyetinin personel maliyetine oranı

C.5. Kullanıma sunulan her bir dokümanın maliyeti

C.6. Her bir kaynak indirmenin maliyeti

C.7. Sağlama hızı

C.8. Kütüphane malzemesinin erişime açılma hızı

C.9. Kütüphane malzemesinin erişime açılma sürecinde çalışanların verimliliği

C.10. Yayınların ödünç verilme hızı

C.11. Kütüphaneler arası ödünç verme hızı

C.12. Doğru cevaplanan soruların oranı

C. 13. Yayınların doğru rafa yerleştirilmesi

İkinci baskıyı ilkinden ayıran en radikal fark olarak kitabın adı görülmektedir. Illk baskıda "Akademik kütüphaneler için performans ölçümü" olan kitabın adı, ikinci baskıda "Kütüphaneler için performans ölçümü" olarak değişmiştir. Kitabın kullanım amacını da belirleyen bu farka göre, ilk baskıda kitap sadece akademik kütüphanelerin performansını belirlemeye yönelik ölçütler sunmaktayken, ikinci baskıda kapsamn genişletilerek halk kütüphanelerinin de dâhil edildiği görülmektedir. Bunun yanı sıra, performans ölçütlerinin aslında bütün kütüphane türlerine uygulanabileceği, ancak kütüphanelerin tür farklılıklarından kaynaklanan özel uygulamaları nedeniyle, bir takım eklemeler ya da çıkartmalar yapılarak mevcut ölçütlerin bütün kütüphane türleri için kullanılabileceği göze çarpan önemli bir yeniliktir. 
Elektronik hizmetler konusunun dışında birinci baskıdan farklı olan konular şu başlıklar altında ele alınabilir (Poll ve Boekhorst, 2007, s.7):

$\checkmark$ Maliyet Etkinliği: Kâr amacı gütmeyen bir hizmet işletmesi olarak kütüphaneler, kendilerine verilen bütçe ve kaynaklar dâhilinde, faaliyetlerini planlamalıdır. Bu zorunluluğun yanı sıra, özellikle devlet kütüphanelerinin hesap verebilirlikleri de önemli bir konudur. Bu ihtiyaçlar doğrultusunda ikinci baskıda altı alan maliyet ya da harcamaların oranları ile ilgili iken, yedi yeni alan iş süreçlerinin etkinliğini ölçmeyi amaçlamaktadır.

$\diamond$ Çalışma mekânı ve buluşma noktası olarak kütüphane: Bütün öngörülerin aksine, kütüphanelerin varlığı fiziksel bir mekân olarak devam etmektedir. Hem basılı hem de elektronik kaynakların ortak olarak kullanıldığı "melez" ya da "karma" olarak adlandırılan kütüphaneler, kullanıcıların grup çalışması isteklerinin artarak devam etmesi sonucu çekici bir yer olmaya devam etmektedir. Bu nedenle yeni baskıda altı alan "fiziksel bir mekân olarak kütüphane" başlığı ile yer almaktadır.

$\checkmark \quad$ Kütüphanenin öğretici rolü: Bilgi kaynaklarında yaşanan köklü değişim, bilgiyi araştırma etkinliğinde de aynı değişimi yaratmıştır. İnsanların aradıkları en küçük bir bilgiyi "Google" üzerinden elde etme isteği "bilgi okuryazarlığı" kavramını doğurmuştur. Nitekim "Google" tarafından sunulan bilgiler her zaman ihtiyaca cevap vermemekte, ilgisiz, sadece anahtar kelimeyi ihtiva eden bilgileri de göstermektedir. Dolayısıyla kütüphanelerin kullanıcılarını bilgi okuryazarı olarak eğitilmesi için yeni baskıda üç alan kütüphanelerin bilgi ve öğretim hizmetlerine ayrılmıştır.

$\diamond$ Kütüphanenin dışarıdan gelen kullanıcılar için fonksiyonları: Pek çok kütüphane, hizmetlerini ve kaynaklarını dışarıdan gelen kullanıcılara da sunmakla birlikte, onları kendi kullanıcılarından farklı algılamaktadırlar. Yeni baskıda bir alan da bu konuya ayrılmıştır.

$\diamond$ Personelin önemi: Değişen ve her geçen gün değişmeye devam eden dünyada kaliteli ve etkin hizmet, o kurumun nitelikli çalışanları tarafından sağlanabilmektedir. Kütüphaneler de bir hizmet işletmesi olarak değişimi takip eden ve değişimle bütünleşmeyi bilen çalışanlardan oluşmalıdır. Bunun önemine dikkat çeken ikinci baskıda iki alan bu konuya ayrılmıştır.

Birinci baskıdaki 17 alanın altısı, ikinci baskıda hiç ele alınmamıştır. Kitapta bu alanlarının neler olduğu net bir şekilde sıralanmamakla birlikte, derme kalitesini ölçmek amaçlı oluşturulan kontrol listesi ya da konu taramalarının başarı oranı gibi gerek teoride etkinliğini kaybetmiş, gerekse uygulamaları son derece zor olan alanlar olduğu belirtilmektedir. Bu alanların yerine ise elektronik hizmetler ikame edilmiştir. 


\section{Ölçütlerin Seçilme Süreci}

Çalışmanın 1996 baskısında belirlenen 17 performans ölçütü, sadece mevcut literatür ve IFLA'nın 1989 ve 1990 yıllarındaki toplantı sonuçlarından faydalanılarak hazırlanmıştır. Çalışmanın 2007 baskısında kullanılan kaynaklar ise şunlardır (Poll ve Boekhorst, 2007, s.10):

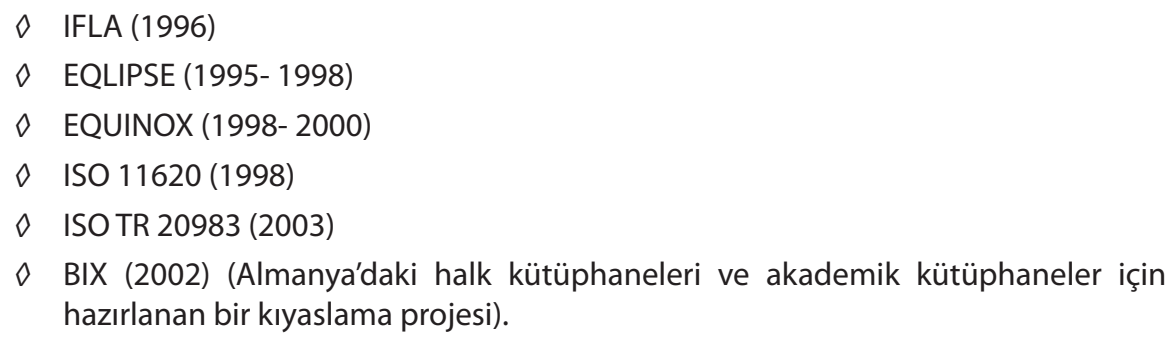

Öncelikle uygulanabilirliği ve etkinliği test edilmiş olan EQLIPSE (1995) ve bu alanda uluslar arası ilk standart olan ISO 11620 kullanılarak 29 ölçüte ulaşılmıştır. Birinci baskıda sadece iki alanda ele alınan fakat, ikinci baskıda özellikle geniş bir yer tutan elektronik kütüphaneler konusunda ise EQUINOX projesi ve elektronik kütüphane hizmetlerini ölçmek amaçlı geliştirilen ISO teknik raporundan yararlanılmış ve bu sayede 14 ölçüt daha geliştirilmiştir. Akademik kütüphanelerin kontrolü için hazırlanan ve bir Alman kıyaslama projesi olan BIX ise, ölçütler hazırlanırken ve seçilirken kullanılan bir başka kaynaktır (Roswitha Poll, 2008, s.31). 1999 yılında sadece halk kütüphaneleri için hazırlanmış olan bu proje, 2002 yılında kapsamı genişletilerek akademik kütüphanelere de uygulanmış ve elde edilen sonuçlar IFLA ölçütlerinin hazırlanmasında geliştirici bir rol oynamıştır.

Yukarıda bahsedildiği gibi, ikinci baskıyı birinci baskıdan ayıran temel farklardan biri yönelinen kitledeki değişim olmuştur. Bu farklılık ölçütlerin belirlenmesinde dikkat edilmesi gereken hususları da etkilemiştir. Buna göre 2007 yılında yayımlanan kitaptaki performans değerlendirme ölçütleri belirlenirken şu hususlara dikkat edilmiştir (Poll ve Boekhorst, 2007, s.9) :

$\diamond$ Hem akademik hem de halk kütüphaneleri alanında genellikle kabul görmüş olan kaynak ve uygulamaları mümkün olduğunca kapsamak.

$\diamond \quad$ Yeni elektronik hizmetler kadar geleneksel kütüphane hizmetlerine de yer vermek ve eğer mümkünse bu ikisini aynı başlık altında ele almak.

$\diamond$ Test edilmiş ve kayda geçirilmiş olan ölçütleri seçmek.

$\diamond$ Kurumsal karne yaklaşımında tanımlandığı şekliyle, hizmet kalitesinin farklı yönlerini kapsamak. 
Poll, birinci baskı için hazırlanan ölçütler tespit edildikten sonra, özel bir çalışma grubunun üyeleri tarafından kendi kütüphanelerinde uygulanmak üzere ölçütlerin test edildiğini ve nihayetinde işlerliği kanıtlanmış olan 17 ölçütün seçildiğini belirtmektedir (Poll, 2008, s.26). Fakat daha sonra yaşanan gelişmeler ve değiş̧en ihtiyaçlar, 17 ölçütün yeterli olmadığını göstermiş; yukarıda anılan çalışmaların da katkısıyla ölçütlerin sayısı 40'a ulaşmış ve mevcut alanlar belirlenmiştir.

\section{IFLA Performans Ölçütleri}

IFLA ölçütleri hazırlanırken yukarıda bahsedildiği gibi "kurumsal karne" yaklaşımı benimsenmiştir. Kurumsal karne, genellikle kâr amacı güden kurumlara uygulanmakta ve bir kurumun etkinliliğini şu dört açıdan ele almaktadır (Poll ve Boekhorst, 2007, s.15)

\section{$\diamond$ Kullanıcılar \\ $\diamond \quad$ Mali durum \\ $\diamond$ Süreçler / İşlemler \\ $\diamond$ Öğrenme ve Gelişme Kapasitesi}

Kütüphanecilik alanına uygulanarak kullanılan bu yaklaşım sonucunda elde edilen ölçütlerden bazıları örnek olarak (kitapta ele alınış şekline sadık kalınarak) sadece fikir vermesi amacıyla ve birebir çeviri yapılmadan burada sunulmuştur. Buna göre öncelikli olarak ölçütün tanımı verilecek, ardından amacı belirtilecek ve daha sonra uygulanabilmesi için izlenmesi gereken metod ve hesaplama şekli sunulacaktır.

\section{IFLA Performans Ölçüt Örnekleri}

\section{A- Kaynaklar ve Altyapı}

\section{A.3. Kullanıcı İstekleri Ille Karşılaştırıldığında Açık Olduğu Saatler}

Tanım: Bu ölçüt, kütüphanenin açık olduğu saat dilimlerinin kullanıcıların açık olmasını istediği saat dilimlerine olan oranını göstermektedir. Kütüphanenin açık olduğu saatler genel anlamıyla, pazartesiden pazara açık olduğu ortalama saatleri ifade etmektedir.

Amaç: Gerek malî gerekse insan kaynaklarının yetersizliğinden dolayı, kütüphanenin açık olduğu saatler ile kullanıcıların açık olmasını istediği saatler arasında fark vardır. Bir kütüphane çevrimiçi olarak 24 saat hizmet veriyor bile olsa, kullanıcı yayını ödünç alabilmek için kütüphanenin haftanın her günü açık olmasını istemektedir. Bu ölçüt sayesinde kütüphaneler, ne kadar süre hizmet vermeleri gerektiğini, haftanın hangi 
günlerinde ve saat dilimlerinde ya da haftanın hangi günlerinde daha uzun süre açık tutulması kararını verebilirler. Dolayısıyla bu ölçüt bütün kütüphaneler için önemlidir.

\section{Metodlar:}

1- Kütüphaneye gelen ya da çıkan 200-300 kişi rastgele seçilip anket yapılarak, kütüphanenin açık olduğu saatlerle ilgili fikirleri alınabilir.

2- Belirli zaman aralıklarında kütüphanenin web sitesine konacak bir çevrimiçi anket formu ile kullanıcıların hangi saat dilimlerinde kütüphanenin açık olmasının istendiği tespit edilebilir.

\section{B-Kullanım}

\section{B.1. Pazara Nüfuz Etme/Pazara Giriş}

Tanım: Pazara nüfuz etme/ pazara giriş, kütüphanenin aktif kullanıcılarının potansiyel kullanıcılarına olan oranını ifade etmektedir.

$\diamond$ Potansiyel kullanıcılar, kütüphanenin temel kullanıcı grubunu (öğrenciler, bir üniversitedeki akademik personel vb.) oluşturmaktadır.

$\diamond \quad$ Aktif kullanıcılar, kütüphanenin belli bir dönemi (akademik yıl ya da dönem, bir takvim yılı vb.) içerisinde bütün kütüphane faaliyetlerinden yararlanan gruptur.

$\diamond \quad$ Aktif kullanıcı grubu statülerine (öğrenci, akademisyen vb.) ya da ilgilendikleri konulara (hukuk, tıp, tarih vb.) göre alt gruplara bölündüğünde, pazar etkisi daha da belirgin hâle getirilmiş olacaktır.

Amaç: Bu ölçütün amacı, aktif kullanıcı sayısının potansiyel kullanıcı sayısına oranını bularak kütüphanenin başarı derecesini ve aynı coğrafi bölgede yer alan kütüphanelerden hangisinin tercih edildiğini belirlemektir.

Metod: Pazar etkisinin başarısını ve doğruluğunu ölçmeyi sağlayan iki metod bulunmaktadır.

1- Kullanıcılara, kütüphane hizmetlerinden son bir yıl içinde hangilerini kullandıklarını ölçen bir anket uygulanabilir. Bu anket sonucunda "evet" cevaplarının oranı "hayır" cevaplarıyla kıyaslanarak kütüphanenin başarı derecesi tespit edilir.

2- Kütüphanenin aktif kullanıcı sayısı potansiyel kullanıcı sayısına bölünerek kütüphanenin tercih edilme oranı bulunabilir.

Hesaplama: Aktif kullanıcıların sayısı, kütüphanenin bulunduğu çevredeki potansiyel kullanıcı sayısına bölünüp 100'le çarpılır. 


\section{B.6. Derme Kullanımı}

Tanım: Derme kullanımı, belli bir zaman süresince kullanılan kütüphane kaynağı sayısının toplam derme sayısına oranını ifade etmektedir. Bu ölçütde derme kullanımı, kütüphanedeki yayınların iç ve dış kullanım dolaşımını_ifade etmektir.

Amaç: Dermeun kullanılma derecesini belirleyen bu ölçüt sayesinde dermeun kalitesi de ortaya çıkmaktadır.

Bu ölçüt kütüphane dermesinin niteliğini ölçmek konusunda en faydalı ölçüt olarak kabul görmektedir. Bu nedenle elde edilecek olan sonuç uyarınca dermeun genişletilmesi ya da bu konuda izlenecek olan politika doğru sonuç verecektir.

Metod: Bu ölçütün uygulanması sırasında aşağıdaki veriler kullanılabilir:

$\diamond \quad$ Belli bir zaman süresinde ödünç alınan yayın sayısı (genellikle 1 yıl)

$\diamond$ Aynı sürede kütüphane içinde kullanım sayısı

$\diamond$ Dermede yer alan yayınların toplam sayısı

Verilerin Toplanması: Belirli bir zaman süresinde ödünç alınan yayınların sayısı ile ilgili verileri elde etmek oldukça kolayken, aynı durum kütüphane içi kullanım sayısını belirlemede geçerli değildir. Nitekim kütüphaneler otomasyon sistemine dâhil olsun ya da olmasın, istatistik tutmak suretiyle ödünç verilen yayın sayısını kolayca elde edebilirler. Ancak kütüphane içindeki kullanımın sayısını tespit edebilmek için daha özel metodlara ihtiyaç duyulmaktadır. Bu metotlar şunlardır:

$\checkmark$ Kullanıcılar tarafından rapor verilmesi: Kullanıcılar kütüphaneden ayrılırken onlara yöneltilecek olan "kaç tane yayın kullandınız?" sorusuna verilecek olan cevabı referans alan bu yöntem, fazla zaman harcanması ya da kullanıcıların kesin sayıları vermemesi gibi bir takım dezavantajlara sahiptir.

$\diamond$ Etiketlere işaret konulması: Kullanıcıların kullandıkları yayınlara işaret koymasını öneren bu yöntemde, yayınların ön kapağında bulunan etiketlerin, yayınının kullanımı sırasında kullanıcı tarafından işaretlenmesi ve böylece o yayının belli bir zaman sürecinde ne kadar kullanıldığının belirlenmesi amaçlanmaktadır. Ancak bir önceki yöntemde olduğu gibi, kullanıcıların işaret koymayı unutması ya da işaretleme yapmayı istememesi gibi nedenlerle doğru verilerin elde edilememesi söz konusu olabilmektedir.

$\diamond$ Yayınların çalışanlar tarafından raflara yerleştirilmesi: Diğer iki yönteme göre daha kullanışlı görünen bu yöntemde, kullanıcıların kullandıkları yayınları masaların üzerinde bırakması istendikten sonra, o yayınlar kütüphane çalışanları tarafından sayılarak raflara yerleştirilmekte, böylece daha net ve doğru veri elde etmiş olmaktadır. 
Hesaplama: Bir kütüphanenin otomasyon sistemi, son 12 aylık ödünç verme sayısını 400.000 olarak belirler. Yine aynı dönemde kütüphane içinde yayın kullanım sayısı ise 160.000 'dir. Buna göre kütüphanede 1 yıl içinde kullanılan yayın sayısı 560.000 olur. Bu kütüphanenin dermesi 420.000 olarak kabul edilirse, derme sayısı bir yıllık kullanım sayısına bölünerek o kütüphanenin dermesinin yıllık olarak ortalama kullanım oranı tespit edilir (1.3). Bu sonucun başarılı olup olmadığı, aynı alanda faaliyet gösteren diğer kütüphanelerle karşılaştırıldıktan (benchmarking) sonra belirlenebilir.

\section{Sonuç}

Geçen zaman içerisinde kütüphanelerdeki elektronik hizmetlerin artmasının, kullanıcı ihtiyaç ve beklentilerindeki farklılıkların ve kütüphanelerin yapısında meydana gelen değişimlerin, kütüphane performans ölçütlerinin belirlenmesinde önemli rol oynadığı görülmektedir. Nitekim ikinci baskıda ele alınan fakat birinci baskıda hiç söz edilmeyen konular arasında, kütüphanelerin birer işletme olarak değerlendirilmesi sayılabilir. İlk baskıda kütüphanelerin maliyet etkinlikleri ile ilgili herhangi bir ölçüte yer verilmeyişi de bu görüşü destekler niteliktedir. Bunun yanı sıra ikinci baskıda kütüphaneler artık sadece birer kaynak sağlama merkezi değil aynı zamanda birer sosyal mekân ve toplumsal misyonu olan kurumlar olarak ele alınmıştır. Bu itibarla kütüphanelere atfedilen görevler arasında, kullanıcılarına bilgi okuryazarlığı eğitimi vermesi de sayılmıştır.

1996 ile 2007 yılları arasında kütüphanecilik alanında yaşanan en büyük etkiyi internetin bir bilgi sağlama merkezi olarak kullanılması yaratmıştır. İnternetin kullanılmasıyla doğan elektronik kütüphanecilik ve dijital kütüphanecilik konularına ait ilk baskıda herhangi bir ölçütün bulunmayışı, yine değişimin kütüphaneler üzerindeki etkisini gösteren açık bir örnektir.

Amacı, bir kurumda etkili bir yönetim için performans ölçümünün önemli bir araç olduğunu göstermek ve kütüphanedeki işsüreçlerini değerlendirmek olan bu ölçütler, 1996 basımında sadece akademik kütüphaneler için yedi genel başlık altında 17 ölçütden oluşmaktayken, 2007 basımında bütün kütüphane türlerine uygulanabilen dört ana başlık altında 40 ölçütten oluşmaktadır. Aradan geçen on bir yıllık sürede, gerek akademik gerekse diğer kütüphane türlerinin değerlendirilmesi ile ilgili ölçütlerin sayısındaki büyük artış, gelişen teknolojinin ve değişen ihtiyaçların derecesinin de bir göstergesi olarak kabul edilmelidir.

\section{Kaynakça}

Akbayrak, E. H. (2005). Orta Doğu Teknik Üniversitesi Kütüphanesinde hizmet kalitesi ölçümü. Yayımlanmamış yüksek lisans tezi, Hacettepe Üniversitesi, Ankara.

Bilgin, N. (2006). Sosyal bilimlerde içerik analizi teknikler ve örnek çalışmalar. Ankara: Siyasal Kitabevi. 
Çakmak, N. ve Ocaklı E. (2006). Performans değerlendirmesi gerekli midir? Neden? UNAK'06 Toplantısı'nda sunulan bildiri. 15 Şubat 2010 tarihinde http://kaynak.unak.org.tr/bildiri/ unak06/406-18.pdf adresinden erişildi.

EQLIPSE (1995-1997). Evaluation and quality in library performance: System for Europe. 21 Nisan 2009 tarihinde http://www.cerlim.ac.uk/projects/eqlipse/ adresinden erişildi.

EQUINOX (1998-2000). Library performance measurement and quality management system. 5 Mart 2009 tarihinde http://www.equinox.dcu.ie/index.html adresinden erişildi.

ISO 11620 (2008). International standard. Information and documentation-library performance indicators. Switzerland: ISO.

Kanık L. (1999). Üniversite kütüphanelerinde performans değerlendirmesi: Kavramsal bir yaklaşım. E. Bilar (Yay. Haz.). 21.yy'da Üniversite Kütüphanelerimiz Sempozyumu Bildirileri: 22-24 Ekim 1998 Edirne içinde (ss.146-156). Edirne: Trakya Üniversitesi.

Karakaş, S. (1991). Başarı değerlendirmesi: Kütüphanelerde ve enformasyon merkezlerinde yeni bir yönetim aracı. Türk Kütüphaneciliği, 5 (4), 161-171.

Law, L. M., Gao, V. X. ve Ng, H. L. (2009). Performance evaluation: A case study of Lee Kong Chian Reference Library. Library Management, 30 (1/2), 77-87.

Liu, Y. Q. (2001). The use of statistics in the managerial process by public library directors in Chine and the USA: A cross-country survey. Library Management, 22 (4/5), 187-194.

Poll, R. (2008). Ten years after: Measuring quality revised. Performance Measurement and Metrics. 9(1), 26-37.

Poll, R. ve Boekhorst, P. (1996). Measuring quality: International guidelines for performance measurement in academic libraries. München: IFLA, K.G. Saur.

Poll, R. ve Boekhorst, P. (2007). Measuring quality performance measurement in libraries (2.bs). München: IFLA. K. G. Saur.

Stephens, D. ve Russell, K. (2004). Organizational development and leadership. Library Trends. 53(1), 248-249. 